\title{
KEDUDUKAN JAMINAN FIDUSIA SERTA PERLINDUNGAN HUKUM BAGI LEMBAGA PEMBIAYAAN KONSUMEN
}

\author{
Oleh: \\ Linda Susilo $^{1}$, Rani Apriani ${ }^{2}$, Rahmi Zubaedah ${ }^{3}$ \\ $1,2,3$ Universitas Singaperbangsa Karawang \\ ${ }^{1}$ 1810631010201@ student.unsika.ac.id; ${ }^{2}$ rani.apriani180488@gmail.com; \\ 3rahmizubaedah@yahoo.com
}

\begin{abstract}
ABSTRAK: Dalam era globalisasi ini tak dapat dipungkiri bahwa setiap kebutuhan seluruh lapisan masyarakat khususnya di Indonesia semakin pesat atau dapat dikatakan meningkat, yang dimana hal ini sangat berbanding dengan pendapatan setiap individu (masyarakat) untuk memenuhi segala kebutuhannya. Sehingga salah satu cara yang dilakukan sebagai pemenuh kebutuhan tersebut muncullah jasa lembaga pembiyaan konsumen, yang terbentuk atas dasar pengajuan hutang pituang atau kredit, dalam kegiatannta melakukan pengadaan arang/memberikan pembiayaan berdasarkan kebutuhan konsumen atau masyarakat dengan sistem pembayaran angsuran yang dalam pelaksanaan kegiatan usaha dan pengelolaan risiko. Sehingga kedudukan jaminan fidusia disini sebagai salah satu jaminan kebendaan untuk dapat memenuhi segala kebutuhan masyarakat, sehingga apabila sewaktu-waktu telah terjadi wanprestasi pada salah satu pihak maka hukum jaminan fidusia ini berperan dalam memberikan kepastian hukum bagi kedua belah pihak yang berkepentingan terutama pada pihak lembaga pembiayaan konsumen.
\end{abstract}

\section{KATA KUNCI: Jaminan Fidusia, Lembaga Pembiayaan, Konsumen}

ABSTRACT: In this era of globalization, it is undeniable that every need of all levels of society, especially in Indonesia is increasing or can be said to increase, which is very compared to the income of each individual (society) to meet all his needs. So that one of the ways that is done as a meeting of these needs arises the services of consumer financing institutions, which are formed on the basis of filing debt pituang or credit, in the activitiesnta conduct charcoal procurement / provide financing based on the needs of consumers or the public with an installment payment system in the implementation of business activities and risk management. So that the position of fiduciary guarantee here as one of the material guarantees to be able to meet all the needs of the community, so that if at any time there has been a default on one of the parties then the fiduciary guarantee law plays a role in providing legal certainty for both interested parties, especially on the part of consumer financing institutions.

KEYWORDS: Fiduciary Guarantee, Financing Institution, Consumer

\section{PENDAHULUAN}

Setiap harinya tidak dapat dipungkiri bahwa segala sesuatunya mengalami perkembangan dan pertumbuhan yang begitu pesat, sama halnya dengan arus globalisasi yang begitu pesat pula, tak terkecuali 
kebutuhan seluruh masyarakat yang semakin bertambah seiring perkembangan zaman untuk memenuhi kebutuhannya dalam segala hal, namun pada faktanya masyarakat sendiri masih sulit terkendala dalam memenuhi kebutuhan hidupnya, perkembangan ekonomi yang begitu pesat ini pula yang sangat berbanding dengan pendapatan masyarakat dalam memenuhi seluruh kebutuhannya. Kehidupan manusia selalu mengalami perubahan sejalan dengan perkembangan dan peningkatan taraf hidup masyarakat. ${ }^{1}$ Maka berbagai metode pun telah diupayakan termasuk hadirnya jasa lembaga pembiayaan konsumen yang dituju untuk meringankan konsumen dalam memenuhi kebutuhannya.

Pembiayaan pada konsumen adalah sebagai kegiatan pembiayaan untuk pengadaan barang/benda yang bersumber pada kebutuhan konsumen yang muncul dengan sistem pembayaran angsuran yang dalam penerapan kegiatan usaha dan pengelolaan risiko, perusahaan pembiayaan konsumen melaksanakan pengaturan jaminan fidusia atas barang atau benda yang dimiliki konsumen tersebut. Jaminan fidusia yang pada dasarnya merupakan selaku jaminan kebendaan untuk memenuhi segala kebutuhan masyarakat yang dikenal dalam hukum positif sangat memberikan keuntungan tersendiri bagi para pelaku konsumen maupun lembaga pembiayaan konsumen. Sehingga dapat dilihat adanya kegiatan ini dapat berjalan untuk para peminjam (konsumen) agar tujuannya dalam dikembalikan secara lancar tidak melakukan wanprestasi. "Fiduciare Eigendomsoverdracht" atau fidusia sering disebut sebagai jaminan hak milik

\footnotetext{
${ }^{1}$ Rustan, Sahban, Andi Risma, "Perlindungan Hukum Pembelian Kendaraan Dalam Perjanjian Pembiayaan Konsumen dan Pelaksanaan Eksekusi Jaminan Fidusia" Supremasi: Jurnal Pemikiran dan Penelitian Ilmu-ilmu Sosial, Hukum, \& Pengajarannya, Volume XVI Nomor 1, April 2021, Hal 1.
}

secara kepercayaan adalah sebuah bentuk jaminan atas benda-benda bergerak selain gadai, yang mempunyai dasar hukum yurispudensi, ${ }^{2}$ sehingga jaminan fidusia merupakan jaminan yang mengutakan suatu kepercayaan yang diselingi dengan suatu jaminan, timbul dari hubungan manusia sehingga apa yang mereka rasakan aman untuk memberikan jaminan bagi mereka yang berhutang. Pada umumnya yang dikatakan sebagai perjanjian ini wajib dibuat dalam bentuk perjanjian baku yang hanya diformulasikan kepada satu pihak saja yaitu pihak pembiayaan konsumen maupun pihak selaku konsumen. ${ }^{3}$ Perjanjian pembiayaan bagi konsumen pula selain dibuat dalam bentuk pejanjian baku, harus dibuat pula berdasarkan atas asas kebebasan berkontrak para pihak yang memuat rumusan kehendak berbentuk hak dan kewajiban dari perusahaan pembiayaan konsumen selaku pihak penyedia dana (fund lender), serta konsumen selaku pengguna dana (fund user).

Dalam perjanjian pembiayaan konsumen memuat dokumen hukum utama yang terbuat secara sah dengan memenuhi ketentuan-ketentuan sebagaimana yang diterapkan dalam pasal 1320 Kitab Undang-Undang Hukum Perdata, yang dimana digunakan sebagai syarat sah dalam suatu perjanjian antara pihak lembaga pembiayaan konsumen dengan konsumen atau debitur, maka akibat hukum dari perjanjian pembiayaan konsumen adalah bahwa perjanjian pembiayaan konsumen mengikat penuh serta berlaku kepada para pihak yang menyepakatinya selayaknya undang-undang yang berlaku. Perjanjian pembiayaan konsumen ini

\footnotetext{
2 Yanuar Kukuh, "Perjanjian pembiayaan konsumen", Jurnal Jurist-diction Vol. 1 No.1, 2018 Hal 2

${ }^{3}$ D.Y. Witanto, 2019, "Hukum Jaminan Fidusia Dalam Perjanjian Pembiayaan Konsumen (Aspek perikatan, Pendaftaran dan Eksekusi) “, Bandung, Hal 119
} 
merupakan sebuah perjanjian timbal balik dimana salah satu pihak memberikan prestasinya dalam bentuk mengadakan pendanaan untuk mengadakan sebuah barang-barang yang dibutuhkan oleh pihak konsumen, yang memiliki ciri khas diantaranya, perjanjian utang pituang, perjanjian jual beli, perjanjian jaminan dan perjanjian asuransi. ${ }^{4}$

Menurut Prof. Subekti, S.H, bahwa hubungan antara perikatan dan perjanjian adalah bahwa perjanjian itu menerbitkan perikatan. Perjanjian adalah sumber perikatan, disamping sumbersumber lain. Suatu perjanjian juga dinamakan persetujuan, karena dua pihak itu setuju untuk melakukan sesuatu. ${ }^{5}$

Hal yang sangat menarik pula dalam proses pembebanan fidusia dalam perjanjian pembiayaan konsumen ialah fidusia ini lahir atas dasar pemberian pembiayaan kepada konsumen atas dasar pembelian terhadap suatu barang secara angsuran kepada pihak penyedia dana. Sehingga ada hubungan erat antara benda yang dijadikan objek jaminan oleh pihak konsumen kepada pihak pemberi dana atau lembaga pembiayaan konsumen. Sehingga sangat diperlukan untuk pendaftan jaminan yang dilakukan oleh lembaga pembiayaan karena jika sewaktu-waktu hal yang tidak diinginkan terjadi atau dapat dikatakan wanprestasi pada salah satu pihak maka jaminan fidusia disini sangat berperan dalam memberikan kepastian hukum bagi kedua belah pihak yang berkepentingan untuk menyelesaikan permasalahan yang kemungkinan hari terjadi. Karena pihak lembaga pembiyaan konsumen disini dapat dikatakan sangat lemah oleh sebab itu pentingnya suatu pendaftaran agar memberikan kekuatan untuk pihak lembaga pembiayaan konsumen. Maka

\footnotetext{
${ }^{4}$ D.Y. Wintanto, Op-cit hal 120

5 Subekti, R. "Hukum Perjanjian”, Intermasa, 2005, Hal 1.
}

dari itu tujuan dari penulisan jurnal ini adalah untuk mengetahui kedudukan jaminan fidusia terhadap Lembaga pembiayaan konsumen di Indonesia dan untuk mengetahui perlindungan hukum bagi Lembaga pembiayaan konsumen di Indonesia.

\section{METODE}

Penelitian ini merupakan penelitian hukum normatif. Penelitian hukum normatif disebut penelitian hukum doktrinal. ${ }^{6}$ Dalam penulisan jurnal ilmiah ini penulis menggunakan penelitian normatif atau penelitian hukum doktriner yang melakukan penelitian kepustakaan yang sumbernya banyak didapatkan dari peraturan-peraturan tertulis atau literatur yang ada hubungannya dengan objek penelitian, karena penelitian ini dilakukan hanya pada peraturan tertulis dan bahan lainnya dan terhadap data yang bersifat sekunder yang kemudian digabungkan secara sistematis.

\section{HASIL DAN PEMBAHASAN}

\section{Kedudukan Jaminan Fidusia Pada Lembaga Pembiayaan Konsumen di Indonesia}

Fiduciare Eigendomsoverdracht atau fidusia sering disebut sebagai jaminan hak milik secara kepercayaan adalah sebuah bentuk jaminan atas bendabenda bergerak selain gadai yang memiliki dasar hukum yurisprudensi. Perbedaan gadai dengan fidusia terletak pada hak milik dan penguasaan barangnya bahwa dalam fidusia yang menjadi jaminan untuk diserahkan kepada kreditor adalah hak milik

\footnotetext{
${ }^{6}$ Aminudin, dan H. Zainal Abidin," Pengantar Metode Penelitian Hukum ", PT. Raja Grafindo Persada, Jakarta, 2008, Hal 118.
} 
sedangkan debitor tetap menguasai barangnya dan berbanding terbalik dalam gadai bahwa hak milik tetap ada dan melekat pada debitor sedangkan penguasaan barangnya ada pada kreditor. Atas dasar hak milik dan penguasaan barang dalam fidusia menyebabkan terjadinya penyerahan secara constitutum possessorium. ${ }^{7}$

Dari definisi tersebut sangat jelas bahwa fidusia dibedakan dari jaminan fidusia, bahwa fidusia adalah suatu proses pengalihan hak kepemilikan dan jaminan fidusia adalah jaminan yang diberikan dalam bentuk fidusia. Ini berarti aturan jaminan fidusia yang diatur dalam Undang-undang Jaminan Fidusia ini adalah aturan jaminan fidusia sebagaimana yang ada dalam "fiducia cum creditore contract", ${ }^{8}$ yaitu jaminan yang dibebankan atas suatu benda bergerak secara fidusia sebagai bagian yang disebut pemberi jaminan dengan kepercayaan, jaminan fidusia lebih dikedepankan didalam Undang-undang Jaminan Fidusia daripada pengertian fidusia itu sendiri, hal ini didasarkan bahwa maksud dari perjanjian fidusia yang dibuat berdasarkan Undang-undang Jaminan Fidusia pada dasarnya adalah proses hubungan hukum dalam dunia usaha yang bertumpu pada unsur saling membantu dan itikad baik pada masingmasing pihak, hal ini dapat terlihat dengan adanya konsep fidusia dan jaminan dalam proses pencapaian fidusia itu sendiri yang dari awal sampai dengan sekarang memiliki ciri khas tidak adanya penguasaan benda jaminan oleh penerima fidusia, namun sebenarnya terhadap benda bergerak keadaan tersebut memiliki risiko yang cukup tinggi.

\footnotetext{
${ }^{7}$ Itok Dwi Kurniawan, 'Perlindungan Hukum Bagi Kreditur Melalui Jaminan Fidusia Dalam Pembiayaan Kredit Kendaraan Bermotor Roda Dua Ditinjau Dari Prespektif UndangUndang Nomor 42 Tahun 1999 Tentang Jaminan Fidusia dan Peraturan Bidang Keuangan' Jurnal Repertorium, Volume IV, No.1, 2017, Hal.121
}

Terbentuknya lembaga pembiayaan konsumen ini didasarkan atas pengajuan hutang piutang atau kredit yang ada di Indonesia tidak harus juga diselingi dengan objek jaminan. Di Indonesia jaminan yang dikenal dalam sistem hukumnya adalah jamina fidusia, ${ }^{9}$ Untuk pertama kalinya lembaga ini mendapat pengakuan pada tanggal 18 Agustus 1932. Dalam suatu sistem jaminan yang baik dan yang benar adalah hukum jaminan yang mengatur asas-asas dan norma-norma hukum agar tidak tumpang tindih (overlapping) antara satu dengan yang lainnya, maka dikeluarkan Undang-undang Jaminan Fidusia merupakan pengakuan resmi yang beroleh dari pengakuan yurispudensi yang bertujuan untuk memberikan perlindungan serta kepastian hukum bagi para pihak yang berkepentingan yang ada didalamnya jaminan fidusia (fiduciare eigendoms overdracht) menurut pasal 1 angka 1 Undang-Undang Jaminan Fidusia adalah pengalihan hak kepemilikan suatu benda atas dasar kepercayaan dengan ketentuan bahwa benda yang hak kepemilikannya dialihkan tersebut tetap dalam pemilik benda. ${ }^{10}$

Sedangkan menurut Oey Hoey Tiong jaminan fidusia merupakan "sebagai jaminan hak milik secara kepercayaan, fidusia merupakan suatu bentuk jaminan atas benda-benda bergerak dan benda-benda yang tidak bergerak yang dapat dibebankan hak tanggungan dan hipotek". Ada asas-asas yang dianut dalam undang-undang fidusia, diantaranya adalah asas kepastian hukum, asas pendaftaran, asas perlindungan yang seimbang, asas

\footnotetext{
8 Gunawan Widjaja dan Ahmad Yani, "Jaminan Fidusia”, Raja Grafindo Persada, Jakarta, 2001. Hal 123.

9 Sunaryo, 2013, "Hukum Lembaga Pembiayaan", Sinar Grafika, Jakarta, Hal 4

10 Undang-Undang No. 42 Tahun 1999 Tentang Jaminan Fidusia Pasal 1 Angka 1
} 
menampung kebutuhan praktik, asas tertulis otentik, asas tertulis otentik, dan asas kedudukan yang kuat kepada kreditur $^{11}$

Asas-asas tersebut harus selalu berjalan secara harmonisasi dengan asas hukum jaminan dalam bidang hukum jaminan kebendaan lainnya.karena tak dapat dipungkiri pasa era zaman seperti ini praktik jaminan fidusia tidak bisa dilepaskan dari pengkreditan yang sangat digemari oleh setiap masyarakat sebagai salah satu pemenuh kebutuhan.

$$
\text { Jaminan fidusia bersifat }
$$

kebendaan yang artinya fidusia mempunyai sifat serta kekuatan yang sama dengan gadai, hipotek, dan hak tanggungan yang sesuai diatur berdasarkan 528 KUHPerdata. Beberapa ciri bahwa jaminan fidusia berkedudukan sebagai jaminan hak kebendaan karena mengandung sifat, absolut, droit de suite, droit de preferen, spesialitas, publisitas.

Bentuk dan isi perjanjian pembiayaan konsumen merupakan perjanjian hutang piutang, debitur (konsumen) diberikan fasilitas pembiayaan objek kredit oleh kreditur (pelaku usaha). ${ }^{12}$ Semua bentuk perjanjian jaminan bersifat accesoir terhadap pokonya, perjanjian jaminan disini tidak akan mungkin ada kalau tanpa adanya perjanjian pokok yang mendasarinya. Perjanjian pembiayaan yang mengandung unsur utang piutang merupakan perjanjian pokok yang dijaminkan dengan fidusia, dimana pihak pembiayaan konsumen ini memberikan sejumlah danany untuk membiayai kebutuhan konsumen sehingga dapat dibebankan untuk memberikan jaminan terhadap utang yang timbul dari

\footnotetext{
11 J. Satrio, 2020 , "Hukum Jaminan dan Hak Kebendaan”, Bandung, Hal. 158

12 Greity Silvana J. Weku, "Perlindungan Hukum Untuk Konsumen Lembaga Pembiayaan (Leasing) Atas Pengambilan Paksa Objek Jaminan Kredit', Lex Privatum Vol. VII/No. 6/Jul-Sep/2019. Hal 2.
}

pembiayaan tersebut. ${ }^{13}$ Dalam proses perjanjian terdapat pula kata sah dalam menyepakati bentuk-bentuk perjanjian seperti yang sesuai dengan pasal 1320 KUHPerdata yang meliputi sepakat mereka yang mengikat dirinya, kecakapan untuk membuat suatu perikatan, suatu hal tertentu, suatu sebab yang halal. ${ }^{14}$

Dari kesepakatan tersebut merupakan suatu proses bertemunya para pihak yang saling mengikat dirinya dalam suatu perjanjian yang lahir karena tidak ada suatu paksaan dari pihak manapun.

Di Inggris pembayaran yang disediakan untuk pengadaan barang kebutuhan konsumen dinamakan dengan istilah "consumer kredit" tetapi di Indonesia sendiri dikenal dengan istilah "pembiayaan konsumen " yang pembiayaannya dibiayai oleh perusahaan pembiayaan (Finnacing Company).

Pembiayaan konsumen merupakan salah satu bidang usaha yang melakukan pembiayaan pengadaan barang untuk kebutuhan konsumen dengan sistem pembayaran angsuran atau secara berkala yang merupakan salah satu bidang usaha pada lembaga pembiayaan. Berdasarkan Peraturan Menteri Keuangan No. 84/PMK.012/2006 tentang perusahaan pembiayaan atau lembaga pembiayaan adalah pembiayaan konsumen (consumer Finance) adalah kegiatan pembiayaan untuk pengadaan barang untuk kebutuhan konsumen dengan sistem pembayar angsuran ${ }^{15}$ sehingga dapat dilihat bahwa perjanjian pembiayaan konsumen mengandung beberapa unsur yang antara lain adalah sebuah kegiatan pembiayaan, ditunjukan untuk mengadakan suatu barang, untuk

\footnotetext{
${ }^{13}$ D.Y. Witanto, Op-cit hal 179

${ }^{14}$ Kitab Undang-undang Hukum Perdata pasal 1320

${ }^{15}$ Peraturan Menteri Keuangan No. 84/PMK. 012/2006

Tentang Perusahaan Pembiayaan Menteri Keuangan,

Pasal 1 Huruf G
} 
memenuhi kebutuhan konsumen, pembayarannya dilakukan secara angsuran atau berkala.

Sebenarnya bahwa pembiayaan konsumen itu sendiri merupakan salah satu bidang usaha lembaga pembiayaan, dinegara kita badan usaha diluar bank dan lembaga keuangan bukan bank yang khusus didirikan untuk melakukan kegiatan yang termasuk dalam atau seluruh bidang usaha lembaga pembiayaan yang disebut lemaga pembiayaan konsumen atau perusahaan pembiayaan (Multi Finance). Secara substansial pula pembiayaan konsumen akan selalu melibatkan tiga pihak, yang terdiri dari, pertama pihak konsumen sebagai pelaku dalam membeli suatu barang atau dapat dikatakan yang tidak memiliki suatu dana yang cukup untuk membeli suatu barang yang dibutuhkan. Kedua, pihak lembaga pembiayaan konsumenyang kedudukannya sebagai pemberi pinjaman dana kepada konsumen untuk membeli suatu barang yang dibutuhkan. Ketiga, penjual atau sebagai pemilik barang. Dalam pembiayaan disini lahirlah hubungan hukum yang diantaranya, perjanjian jual beli, perjanjian utang piutang, serta perjanjian penjamin.

Sehingga dapat dikatakan bahwa kedudukan lembaga jaminan fidusia dengan pembiayaan konsumen terletak pada pembiayaan konsumen yang dimana peran konsumen disini adalah sebagai nasabah yang mempunyai hubungan hukum dalam melakukan suatu perjanjian atau hukum kontrak (hubungan kontrak) yang memiliki kesamaan dalam prinsipprinsip dengan perjanjian kredit yang mencakup jaminan pokok, jaminan utama dan jaminan tambahan. Adapun hal-hal yang sangat menarik dalam proses pembebanan jaminan fidusia ada didalam perjanjian pembiayaan konsumen yang dimana benda tersebut harus dijadikan jaminan secara fidusia oleh pihak konsumen kepada pihak lembaga pembiayaan. Sebenarnya dalam fasilitas pembiayaan konsuen perjanjian jaminan merupakan perjanjian ikutan (assesoir) dari perjanjian pembiayaan, meskipun dalam akta perjanjian pembiayaan telah disebutkan bersama-sama dengan perjanjian pembiayaan namun untuk memenuhi ketentuan pasal 5 ayat (1) UU Jaminan Fidusia, maka perjanjian jaminan (fidusia) dibuat lagi secara tersendiri dengan sebuah akta notaris. Perjanjian jaminan ini merupakan sebuah perjanjian obligatoir sehingga sejak awal disepakati atau ditandatangani akta tersebut maka timbullah hak dan kewajiban diantara kedua belah pihak yang saling sepakat. ${ }^{16}$ Seperti bukti bahwa perjanjian jaminan fidusia merupakan perjanjian obligatoir dapat dilihat pada klausa yang berbunyi pada akta pemberi fidusia, "pemberi dan penerima fidusia telah sepakat dan setuju dengan ini mengadakan perjanjian."

Seperti contoh dalam hal proses pemberian jaminan fidusia yang objeknya dalam kendaraan maka terdapat hal yag menarik mengingat pada jenis kendaraan yang sifat kepemilikannya tida tunduk pada ketentuan didalam pasal 1977 ayat (1) KUHPerdata meskipun kendaraan tersebut masuk kedalam benda bergerak, yang artinya bahwa seorang pemilik benda tersebut secara yuridis adalah otrangyang tercantum namanya dalam BPKB. Jaminan fidusia yang membebani benda berupa kendaraan bukan hanya diikatkan oleh sebuah perjanjian pemberian jaminan, namun ada kewajiban pula bagi pihak konsumen ytang menyerahkan BPKB kepada pihak pemberi jaminan sebagai bentuk retensi sebelum hutangnya lunas pihak kreditur pun berhak untuk menahan BPKB

\footnotetext{
${ }^{16}$ D.Y. Witanto, Op-cit Hal 124
} 
tersebut. ${ }^{17}$ Sehingga objek jaminan dalam perjanjian pembiayaan ini adalah benda yang pengadaannya dibiayai atau diberikan pinjaman oleh pihak lembaga pembiayaan yang harus didaftarkan kepada lemvaga jaminan fidusia agar setiap pihak-pihak yang terlibat didalam suatu perjanjian tersebut mempunyai kedudukan yang kuat. Sesuai dengan petauran Menteri Keuangan hubungannta terletak pada pasal 1 dimana perusahaan pembiayaan sebagai mana yang telah disebutkan wajib mendaftarkan ke kantor jaminan fidusia.

Dengan lahirnya jaminan ini pula akan mengubah suatu sistematika kepemilikan yang sebelumnya yang dimana kendaraan tersebut sebagai milik debitur yang dialihkan kepada pihak kreditur, tetapi walaupun sistematika seperti itu pihak debitur tetap menguasai dan dapat menggunakan objek jaminannya itu. Dan kedudukan jaminan fidusia merupaka bentuk pengecualian dari jaminan gadai dimana pada prinsipnya jaminan gadai, benda yang menjadi objek jaminannya yang diserahkan kepada kreditur dan sedangkan fidusia penyerahan hak milik hanya bersifat atas asas kepercayaan dengan memberikan suatu jaminan.

\section{Perlindungan Hukum Bagi Lembaga Pembiayaan Konsumen}

Tujuan dari pendaftaran jaminan fidusia selain untuk melahirkan hak kebendaan yang memenuhi asas publisitas, juga sangat efektif dalam memberikan perlindungan bagi kepentingan kreditur (lembaga pembiayaan konsumen). UndangUndang No. 42 Tahun 1999 tentang Jaminan Fidusia sebagaimana yang telah menyebutkan bahwa Undang-Undang ini memiliki tujuan untuk memberikan suatu pengaturan yang lebih lengkap dari yang selama ini ada dan sejalan untuk memberikan hak istimewa bagi pihak kreditur guna pelunasan hutang-piutang debitur, bahwasannya setelah pasca kontrak posisi kreditur ini sangat lemah maka dari itu pula Undang-Undang fidusia ini mengambil satu prinsip seperti yang dijelaskan bahwa pentingnya suatu pendaftaran yang dimana sangat diharapkan agar dapat memberikan suatu perlindungan hukum yang kuat kepada pihak penerima jaminan (kreditur).

Secara A Contrario dapat dikatakan bahwa apabila debitur tidak memenuhi kewajiban melakukan prestasi, maka apat dikatakan debitur tersebut waprestasi. ${ }^{18}$ Karena sering terjadi bahwa lembaga pembiayaan konsumen merasa telah memiliki semua hak kebendaan atas objek jaminan ketika telah ditandatangani, sehingga banyak kasus yang terjadi dimana lembaga pembiayaan konsumen (kreditur) melakukan pengambilan objek jaminan dalam bentuk kendaraan dengan cara yang tidak layak/patut yang misalnya dicegat dijalan raya lalu kendaraan tersebut diambil secara paksa dan pada saat itu pihak debitur (konsumen) pun tidak kehabisan akal, ia melapor kepada pihak yang berwajib atas tuduhan pencurian dengan kekerasan ketika dimana pihak lembaga pembiayaan pun tidak bisa menunjukkan sertifikat fidusia, maka ini bisa menjadi boomerang baik pada pihak eksekutor maupun pihak lembaga pembiayaan. tetapi beda halnya jika telah didaftrakan dan lahirlah hak kebendaan dari jaminan fidusia itu, maka pihak lembaga pembiayaan akan diberikan hak untuk memenuhi sendiri pelaksanaan pelunasan piutang baik

\footnotetext{
${ }^{18}$ Tan Kamello, 2019, “Hukum Jaminan Fidusia Suatu Kebutuhan Yang didambakan", Bandung, hal 237
}

${ }^{17}$ Ibid, Hal 135 
secara parate eksekusi, eksekusi grosse berdasarkan ketentuan pasal 224 HIR. ${ }^{19}$

Sesuai dengan pasal 11 UUJF yang merupakan asas yang paling penting adalah pendaftaran yang dimana pendaftaran tersebut wajib untuk dilakukan pada kantor pendaftaran jaminan fidusia dilingkup tugas pada kantor Kehakiman dan Hak Asasi Manusia Republik Indonesia. Adapun asas yang dianut tersebut antara lain adalah asas kepastian hukum, asas pendaftaran, asas perlindungan yang seimbang asas menampung kebutuhan praktek, asas tertulis otentik, asas pemberian kedudukan yang kuat kepada kreditur.

Didalam suatu perjanjian antara pihak kreditur dengan debitur biasanya disepakati suatu perjanjian tertentu yang dimana maksud dan tujuannya untuk memberikan suatu posisi kuat bagi pihak kreditur (lembaga pembiayaan konsumen) jika sewaktu-waktu debitur tidak melaksanakan prestasinya, adapun pendaftaran dilakukan melalui suatu permohonan yang ditunjukan kepada kantor jaminan fidusia atau yang dapat disingkat menjadi K.P.F. dalam pasal 14 UUJF disebutkan bahwa kantor pendaftaran fidusia menerbitkan dan menyerahkan kepada penerima fidusia sertifikat jaminan fidusia pada tanggal yang sama dengan tanggal penerima permohonan pedaftaran; sertifikat jaminan fidusia yang merupakan salinan dari buku daftar fidusia memuat catatan tentang hal-hal sebagaimana dimaksud dalam pasal 13 ayat (2) UUJF; jaminan fidusia lahir pada tanggal yang sama dengan tanggal dicatatnya jaminan fidusia dalam buku daftar fidusia. ${ }^{20}$

\footnotetext{
${ }^{19}$ D.Y. Witanto, Op-cit hal 127

${ }^{20}$ Undang-Undang No. 42 Tahun 1999 tentang Jaminan Fidusia Pasal 14

${ }^{21}$ J. Satrio, Op-cit hal 175

${ }^{22}$ Yuoky Surinda, "Perlindungan Hukum Bagi Pihak Kreditur dalam Perjanjian Kredit Dengan Jaminan
}

Dimana pendaftaran jaminan tersebut menganut pula asas spesialitas yang dilihat dari syarat-syarat pendaftaran seperti yang disebutkan dalam pasal 13 ayat (2) yang asasnya sama pula dengan pasal 6 UndangUndang No. 42 tahun 1999 tentang Jaminan Fidusia. ${ }^{21}$

Serta dalam pasal 15 UUJF yang pada intinya menyebutkan bahwa pada benda yang dibebani dengan fidusia wajib didaftarkan dan kemudian dibuat sertifikat jaminan fidusia yang mencantumkan pula "DEMI KEADILAN DAN KETUHANAN YANG MAHA ESA."22 Sehingga dalam pasal 15 tersebut menerangkan bahwa dalam sertifikat jaminan fidusia tersebut mempunyai kekuatan eksekutorial yang sama dengan halnya putusan pengadilan yang telah mempunyai kekuatan hukum tetap. Dalam hal melaksanakan eksekutorial ini kreditur mempunyai hak untuk melaksanakannya apabila debitur wanprestasi sesuai ang tercantum dalam sertifikat jaminan fidusia. Bentuk wanprestasi pada perjanjian jaminan fidusia pula wajib disepakati bersama antara para pihak untuk menentukan bahwa ketika nantinya debitur cedera janji, dan tidak boleh dinyatakan secara sepihak. Selain itu pula adanya sertifikat jaminan fidusia tidak serta merta membuat penerima fidusia dapat langsung mengeksekusi objek jaminan. Karena pada dasar mekanisme dan prosedur hukum dalam pelaksanaan eksekusi sertifikat harus selayaknya eksekusi putusan pengadilan yang telah berkekuatan hukum tetap. ${ }^{23}$

Hal yang lain pula guna melindungi oihak lembaga pembiayaan konsumen maka

Fidusia."Jurnal Hukum Media Bhakti, Vol. 2 No. 1 Hal 29

${ }^{23}$ Sigar Aji Poerana, 2020. "Perlindungan Kepentingan Kreditur dalam "Pidusia" https://www.hukumonline.com/klinik/detail/ulasan/cl2 739/perlindungan-kepentingan-kreditur-dalam-fidusia/ diakses pada 03 April 2021 pukul 19.21 WIB 
perusahan pula harus menerapkan beberapa prinsip umum dalam pelaksanaan pengkreditan yaitu $4 \mathrm{P}$ (Personality, Purpose, Prosfect, Payment) dan formula 5C (Collateral, Capacity, Character, Capital, Condition of Ecomony). Tetapi yang cukup digunakan dala penerapan prinsip adalah 3P yaitu, pertama Personality yang dimana pihak pembiayaan konsumen harus mencari data secara lengkap mengenai kepribadian calon konsumen, riwayat hidupnya karena harus dipertanyakan apakah seorang calon konsumen tersebut beritikad baik atau tidak. Kedua Purpose dimana mencari tahu data apa tujuan penggunaan barang tersebut oleh pihak konsumen. Ketiga Payment pihak lembaga pembiayaan harus mengetahui pula mengenai kemampuan seseorang dalam melaksanakan pembayaran untuk melunasi segala hutang dalan jumlah dan jangka waktu yang telah ditentukan. Selain prisnip itu pula harus menerapkan prinsip 4C yang diantaranya, pertama Character calon konsumen harus mempunyai watak dan sifat pribadi yang baik, penilaian karakter ini meningkatkan kejujuran pada calon konsumen. Kedua Collateral jaminan untuk pengamanan atas risiko yang mungkin terjadi atas wanprestasinyta seorang konsumen. Ketiga Condition of Economy yang meliputi pekerjaan atau penghasilan dari calon konsumen dalam pelaksanaan pembayaran sehingga terhindar dari risiko yang mungkin akan terjadi. Keempat Capacity merupakan kemampuan seorang konsumen untuk dapat melunasi hutang sesuai dengan jumlah dan jangka waktu yang telah ditentukan. ${ }^{24}$

\footnotetext{
24 Endang Prasetyawati, "Perlindungan Hukum Terhadap Para Pihak Pembiayaan Konsumen” Jurnal Ilmu Hukum DIH, Vol. 8 No. 16, 2012 Hal 65
}

\section{PENUTUP}

Dalam suatu sistem jaminan yang baik dan benar adalah hukum jaminan yang mengatur asas-asas dan normanorma hukum agar tidak tumpang tindih (overlapping) antara satu dengan yang lainnya, maka dikeluarkan pula UndangUndang jaminan fidusia merupaka suatu pengakuan resmi yang beroleh pengakuan melalui Yurispudensi yang bertujuan untuk memberikan perlindungan atau kepastian hukum bagi para pihak yang berkepentingan yang ada didalamnya. Asas-asas tersebut harus berjalan secara harmonisasi dengan asas hukum jaminan dalam bidang hukum jaminan kebendaan lainnya. Hal-hal yang sangat menarik dalam proses pembebanan jaminan fidusia ada didalam perjanjian pembiayaan konsumen yang dimana jaminan fidusia disini lahir atas dasar pembelian suatu barang, sehingga terdapat hubungan erat antara keduanya yang dimana benda tersebut harus dijadikan jaminan secara fidusia oleh pihak konsumen kepada pihak lembaga pembiayaan konsumen.

Undang-Undang fidusia sebagaimana telah menyebutkan bahwa undangundang ini memiliki tujuan untuk memberikan suatu pengaturan yang lebih lengkap dari yang selama ini ada dan sejalan untuk memberikan perlindungan hukum yang lebih baik bagi para pihak yang berkepentingan. Atau dapat pula memberikan hak istimewa bagi pihak lembaga pembiayaan konsumen guna pelunasan hutang debitur, karena bahwasannya setelah pasca kontrak posisi kreditur sangat lemah maka dari itu undang-undang fidusia ini mengambil suatu prinsip seperti yang telah dijelaskan bahwa pentingnya suatu pendaftaran 
sangat diharapkan agar dapat memberikan suatu perlindungan hukum yang kuat kepada pihak penerima jaminan. Selain itu pula guna melindungi lembaga pembiayaan, perusahaan harus menerapkan beberapa prinsip umum dalam pelaksaaan pengkreditan yaitu $4 \mathrm{P}$ dan 5C.

\section{DAFTAR PUSTAKA}

\section{Buku}

Aminudin, dan H. Zainal Abidin, "Pengantar Metode Penelitian Hukum", PT. Raja Grafindo Persada, Jakarta, 2008, 118.

Gunawan Widjaja dan Ahmad Yani, "Jaminan Fidusia", Raja Grafindo Persada, Jakarta, 2001. 123.

Kamello, Tan. 2019. Hukum Jaminan Fidusia Suatu Kebutuhan Yang Didambakan, Bandung: P.T. Alumni.

Witanto, D.Y. 2019. Hukum Jaminan Fidusia Dalam Perjanjian Pembiayaan Konsumen (aspek perikatan, pendaftaran, dan eksekusi), Bandung: CV Mandar Maju.

Satrio, J. 2020. Hukum Jaminan dan Hak Kebendaan, Bandung: PT Citra Aditya Bakti

Subekti, R. "Hukum Perjanjian", Intermasa, 2005, 1.

Sunaryo. 2013. Hukum Lembaga Pembiayaan, Jakarta: Sinar

Jurnal Grafika

Greity Silvana J. Weku, "Perlindungan Hukum Untuk Konsumen Lembaga Pembiayaan (Leasing) Atas Pengambilan Paksa Objek Jaminan Kredit', Lex Privatum Vol. VII/No. 6/Jul-Sep/2019. 2.

Prasetyawati, E. 2012. Perlindungan Hukum Terhadap Para Pihak
Pembiayaan Konsumen. Jurnal Ilmu Hukum DIH, 8(16), 101111.

Itok Dwi Kurniawan, Perlindungan Hukum Bagi Kreditur Melalui Jaminan Fidusia Dalam Pembiayaan Kredit Kendaraan Bermotor Roda Dua Ditinjau Dari Prespektif UndangUndang Nomor 42 Tahun 1999 Tentang Jaminan Fidusia dan Peraturan Bidang Keuangan' Jurnal Repertorium, Volume IV, No. 1, 2017; 121.

Rustan, Sahban, Andi Risma, "Perlindungan Hukum Pembelian Kendaraan Dalam Perjanjian Pembiayaan Konsumen dan Pelaksanaan Eksekusi Jaminan Fidusia" Supremasi: Jurnal Pemikiran dan Penelitian Ilmu-ilmu Sosial, Hukum, \& Pengajarannya, Volume XVI Nomor 1, April 2021, 1.

Surinda, Y. 2018. Perlindungan Hukum Bagi Pihak Kreditur Dalam Perjanjian Kredit Dengan Jaminan Fidusia, Jurnal Hukum Media Bhakti, 2 (1), 19-31.

\section{Peraturan Undang-Undang}

Kitab Undang-Undang Hukum Perdata Undang-undang Republik Indonesia Nomor 42 Tahun 1999 Tentang Jaminan Fidusia.

Peraturan Menteri Keuangan Republik Indonesia Nomor 84/PMK. 012/2006 tentang Perusahaan Pembiayaan Menteri Keuangan. 